\title{
Pemanfaatan Citra Landsat 8 Multitemporal dan Model Forest Canopy Density (FCD) untuk Analisis Perubahan Kerapatan Kanopi Hutan di Kawasan Fakultas Geografi Uni- versitas Gadjah Mada Gunung Kelud, Jawa Timur
}

\author{
Shafira Himayah ${ }^{1}$ Hartono $^{2}$ dan Projo Danoedoro ${ }^{3}$
}

Fakultas Geografi, Universitas Gadjah Mada, Yogyakarta, Indonesia ${ }^{123}$

Email Koresponden:shafirahimayah@gmail.com

Diterima: 15Agustus 2016 /Disetujui:22 Februari 2017/ Publikasi online: 31 Maret 2017

(๑) 2017 Fakultas Geografi UGM dan Ikatan Geograf Indonesia (IGI)

\begin{abstract}
Abstrak Penginderaan jauh memiliki keunggulan dalam hal resolusi temporal yang dapat dimanfaatkan untuk meneliti perubahan suatu obyek dalam waktu yang berbeda. Hutan Gunung Kelud mengalami perubahan setelah erupsi tahun 2014. Perubahan tersebut dapat dianalisis dengan memanfaatkan teknologi penginderaan jauh melalui citra multitemporal. Penelitian ini bertujuan untuk mengkaji kemampuan citra Landsat 8 multitemporal dan Forest Canopy Density (FCD) untuk perubahan kerapatan kanopi di Hutan Lindung Gunung Kelud sebelum dan sesudah erupsi tahun 2014. Citra penginderaan jauh yang digunakan adalah citra Landsat 8 perekaman 26 Juni 2013 dan 4 September 2015. Metode yang digunakan adalah pemodelan FCD yang menghasilkan kerapatan kanopi per piksel. Hasil pemodelan FCD kemudian digunakan untuk menganalisis perubahan kerapatan kanopi setelah erupsi. Berdasarkan penelitan ini didapatkan hasil bahwa citra Landsat 8 dapat dipergunakan untuk mengetahui kerapatan kanopi Hutan Lindung Gunung Kelud sebelum dan setelah erupsi dengan masing-masing akurasi sebesar $83,73 \%$ dan $81,14 \%$. Terjadi perubahan luas kerapatan kanopi setelah erupsi, dimana terdapat 8833,95 Ha hutan yang mengalami penurunan kerapatan kanopi, sedangkan hutan dengan kerapatan kanopi yang tetap adalah seluas 2149,38 Ha, dan hutan yang mengalami peningkatan kerapatan kanopi adalah seluas 1643,31 Ha.
\end{abstract}

Kata kunci: Landsat 8, pemodelan FCD, perubahan kerapatan kanopi

\begin{abstract}
Remote sensing has an advantage in terms of temporal resolution that can be exploited to examine the changes of an object in different times. Gunung Kelud Forest is changing after eruption in 2014. The changes can be analyzed by utilizing remote sensing technology through multitemporal imagery. This study aims to examine the capabilities of Landsat 8 multitemporal and Forest Canopy Density (FCD) images for changes in canopy density in Kelud Protection Forest before and after eruption in 2014. Remote sensing imagery used is Landsat 8 image recording June 26, 2013 and September 4, 2015 The method used is FCD modeling that produces density of the canopy per pixel. FCD modeling results are then used to analyze changes in density of the canopy after eruption. Based on this research, it can be concluded that Landsat 8 image can be used to determine the density of canopy of Kelud Protection Forest before and after eruption with $83.73 \%$ and $81.14 \%$ accuracy respectively. There was a change in the area of the canopy density after the eruption, where there were 8833.95 ha of forest that experienced a decrease in canopy density, whereas forests with fixed canopy densities were $2149.38 \mathrm{Ha}$, and forests with an increase in canopy density were $1643.31 \mathrm{Ha}$.
\end{abstract}

Keywords: Landsat 8, FCD modeling, canopy density change

\section{PENDAHULUAN}

Penginderaan jauh memiliki keunggulan dalam hal resolusi temporal. Perbedaan waktu perekaman (resolusi temporal) citra penginderaan jaun dapat digunakan untuk memantau fenomena atau obyek di permukaan bumi yang mengalami perubahan dalam kurun waktu tertentu. Obyek yang direkam pada waktu yang berbeda memungkinkan adanya variasi pantulan spektral obyek, seperti misalnya pantulan spektral vegetasi yang dapat dipengaruhi oleh musim yang sedang berlangsung. Vegetasi sebagai salah satu obyek yang dapat dikenali melalui citra satelit memiliki pantulan spektral yang khas pada saluran inframerah, sehingga saluran tersebut merupakan saluran yang sesuai untuk dipakai meneliti vegetasi, termasuk kumpulan vegetasi yang membentuk hutan.

Landsat 8 memiliki 11 saluran, saluran ke 5 adalah saluran inframerah yang memiliki kegunaan dalam identifikasi obyek berupa vegetasi. Berdasarkan hal tersebut, sampai saat ini telah banyak dilakukan penelitian penginderaan jauh dalam bidang vegetasi termasuk diantaranya adalah mengenai hutan. Keunggulan penginderaan jauh dalam hal multiwaktu serta pantulan vegetasi yang khas pada saluran inframerah memungkinkan untuk dilakukannya penelitian terhadap perubahan kerapatan kanopi hutan sebagaimana yang terjadi pada kawasan hutan lindung Gunung Kelud.

Model yang dapat digunakan untuk meneliti kerapatan kanopi hutan adalah Forest Canopy Density (FCD). Keunggulan dari model FCD adalah perhitungan mengenai kerapatan kanopi hutan tidak semata-mata mempertimbangkan faktor vegetasi saja, temperatur dan tanah terbuka yang berkorelasi negatif terhadap vegetasi juga turut dipertimbangkan, begitu pula dengan bayangan yang memiliki korelasi negatif terhadap vegetasi. Keunggulan lainnya adalah, FCD dapat digunakan untuk mengkaji komposisi struktural 
hutan berdasarkan persentase hasil pemodelan.

Hal ini tentu saja menjadikan FCD sebagai model yang baik untuk menganalisi kerapatan kanopi hutan yang mengalami perubahan setelah terjadinya erupsi. Data berupa persentase per piksel mengenai keempat faktor pada model FCD diperoleh dari advance vegetation index (AVI), bare soil index (BI), shadow index (SI), dan thermal index (TI), (Rikimaru, 2002).

Penelitian ini bertujuan untuk mengkaji kemampuan citra Landsat 8 multitemporal dan Forest Canopy Density (FCD) untuk perubahan kerapatan kanopi di Kawasan Hutan Lindung Gunung Kelud sebelum dan sesudah erupsi tahun 2014.

\section{METODE PENELITIAN}

Penelitian ini dilakukan di hutan Gunung Kelud yang secara administratif terletak di wilayah Kabupaten Kediri, Kabupaten Blitar, dan Kabupaten Malang. Puncak Gunung Kelud berada pada ketinggian 1731 meter di atas permukaan laut dan terletak di Kecamatan Ngancar, Kabupaten Kediri. Gunung Kelud terakhir kali meletus pada tanggal 12-14 Februari 2014 yang menyebabkan terjadinya kerusakan hutan.

Hutan Gunung Kelud terletak pada 112014'00"112o22'20"BT dan 7o51'40" - 8o0o40"LS dengan luas kurang lebih 13.381 hektar. Menurut ketinggiannya, hutan Gunung Kelud termasuk ke dalam zona hutan hujan bawah (0-1.000 mdpl) dan hutan hujan tengah (1.000-3.300 mdpl) (Indriyanto, 2012).

Data yang digunakan untuk medapatkan kerapatan kanopi hutan adalah citra Landsat 8 perekaman tanggal 23 Juni 2013 dan 4 September 2015. Kedua citra tersebut masing-masing merepresentasikan kondisi hutan Gunung Kelud sebelum dan sesudah erupsi. Landsat 8 diluncurkan pada tanggal 11 Februari 2013 dan memiliki 11 saluran spektral yang terdiri dari : saluran Coastal $(0,43-0,45 \mu \mathrm{m})$, Biru $(0,45-$ $0,51 \mu \mathrm{m})$, Hijau $(0,53-0,59 \mu \mathrm{m})$, Merah $(0,64-0,67 \mu \mathrm{m})$, Inframerah dekat $(0,85-0,88 \mu \mathrm{m})$, SWIR $1(1,57-$ $1,65 \mu \mathrm{m})$, SWIR $2(2,11-2,29 \mu \mathrm{m})$, Pankromatik $(0,50$ $0,68 \mu \mathrm{m})$, Cirrus $(1,36-1,38 \mu \mathrm{m})$, Inframerah thermal 1 $(10,6-11,9 \mu \mathrm{m})$, dan Inframerah thermal 2 (11,5-12,51 $\mu \mathrm{m})$. Selain itu, penelitian ini juga menggunakan Peta Rupa Bumi Indonesia yang akan dijadikan acuan saat melakukan koreksi geometrik citra, serta digunakan untuk mendapatkan data batas adminsitratif daerah penelitian.

Sebelum melakukan pemodelan kerapatan kanopi, citra Landsat 8 dikoreksi terlebih dahulu. Adapun koreksi yang dilakukan adalah koreksi geometrik dan koreksi radiometrik. Koreksi geometrik dilakukan dengan metode image to map, yaitu menggunakan peta RBI sebagai acuan untuk melakukan koreksi. Peta yang digunakan sebagai acuan adalah Peta Rupa Bumi Indonesia.

Koreksi radiometrik dilakukan untuk normalisasi saluran citra, koreksi radiometrik yang dilakukan pada penelitian ini dibagi menjadi dua tahap, yaitu konversi nilai digital ke nilai radian dan nilai reflektan, dan koreksi topografi. Khusus untuk band 10 (thermal) dilakukan koreksi radiometrik hingga mendapatkan nilai temperatur, sedangkan band lainnya dikoreksi sampai ke nilai reflektan.

Forest Canopy Density merupakan salah satu metode untuk mengestimasi kerapatan kanopi hutan dengan mempertimbangkan faktor vegetasi, tanah terbuka, temperatur, dan bayangan. Pemetaan dan pemantauan menggunakan model Forest Canopy Density (FCD) memanfaatkan kerapatan kanopi hutan sebagai parameter yang digunakan untuk merepresentasikan karakteristik kondisi hutan. Indeks yang digunakan dalam pemodelan FCD antara lain adalah Advanced Vegetation Index (AVI), Bare Soil Index (BI), Shadow Index atau Scaled Shadow Index (SSI) dan Thermal Index (TI). (Rikimaru, 2002). Keempat indeks tersebut menggunakan band 2 (biru), band 3 (hijau), band 4 (merah), band 5 (inframerah dekat), band 6 (inframerah tengah 1), band 7 (inframerah tengah 2), dan band 10 (inframerah tengah) pada Landsat 8.

Advanced Vegetation Index (AVI) merupakan salah satu indeks yang menguji karakteristik klorofil vegetasi. Indeks tersebut menggunakan persamaan : $\mathrm{AVI}=(($ Band5 +1$)(256-$ Band4 $)($ Band5 - Band4 $)) 1 / 3$ (2.1)

Bare Soil Index (BI) dirumuskan dengan memanfaatkan band inframerah tengah, band inframerah dekat, band merah, dan band biru. Respon dari tanah terbuka, lahan kosong, dan vegetasi ditingkatkan melalui indeks ini. Adapun persamaan BI adalah sebagai berikut :

$(((\mathrm{B} 6+\mathrm{B} 4)-(\mathrm{B} 5+\mathrm{B} 2)) /(((\mathrm{B} 6+\mathrm{B} 4)+(\mathrm{B} 5+\mathrm{B} 2))) \times 100+100$ ......... (2.2)

Shadow Index (SI) merupakan perhitungan yang menguji karakteristik bayangan dengan memanfaatkan informasi spektral dari bayangan hutan, dengan rumus sebagai berikut :

$\mathrm{SI}=((256-$ Band2 $) \times(256-$ Band 3$) \times(256-$ Band 4$)) 1 / 3$ (2.3)

Thermal Index (TI) merupakan indeks yang didasarkan pada dua faktor yang mempengaruhi relativitas dingin tidaknya kondisi di dalam hutan. Faktor yang pertama adalah efek shielding dari kanopi hutan yang menghalangi dan menyerap energi dari matahari. Faktor yang kedua adalah evaporasi dari permukaan daun yang mengurangi pemanasan. Data mengenai temperatur digunakan untuk memisahkan tanah dan bayangan non pohon.

Kalibrasi temperatur dari saluran inframerah termal ke nilai temperatur tanah didapatkan dengan terlebih dahulu merubah nilai digital pada saluran termal menjadi nilai radian. Setelah didapatkan nilai radian, selanjutnya dilakukan konversi ke temperatur kecerahan dilakukan pada band 10. Persamaan yang digunakan untuk mengubah nilai radian tersebut adalah :

$\mathrm{T}=\mathrm{K} \_2 /\left(\ln \left(\mathrm{K} \_1 / \mathrm{L} \_\lambda+1\right)\right)$. 
Keterangan :

$\mathrm{T}=$ brightness temperature $(\mathrm{K})$

$\mathrm{L} \lambda=$ nilai $\operatorname{radian}\left(\right.$ Watts $\left./\left(\mathrm{m} 2{ }^{*} \operatorname{srad}{ }^{*} \mu \mathrm{m}\right)\right)$

$\mathrm{K} 1$ = konstanta konversi thermal pada band 10 ,

$\mathrm{K} 2$ = konstanta konversi thermal pada band 10,

Vegetasi dan parameter berupa bayangan hutan berkorelasi satu sama lain. Jumlah vegetasi meningkat seiring dengan peningkatan bayangan sehingga ketika kerapatan hutan meningkat, bayangan di bawahnya pun bertambah yang kemudian menyebabkan nilai SI meningkat. Thermal Index meningkat saat kuantitas vegetasi menurun dikarenakan saat tanah lebih terbuka (menandakan kurangnya tutupan vegetasi) suhu menjadi lebih meningkat. Menurut Rikimaru (2002), Kombinasi antara empat indeks yang digunakan dalam pemodelan FCD kemudian akan menghasilkan korelasi antar keempatnya.

Tabel 1. Karakteristik Kombinasi antara empat indeks

\begin{tabular}{lllll}
\hline Indeks & $\begin{array}{l}\text { FCD } \\
\text { tinggi }\end{array}$ & $\begin{array}{l}\text { FCD } \\
\text { rendah }\end{array}$ & Semak & $\begin{array}{l}\text { Tanah } \\
\text { Terbuka }\end{array}$ \\
\hline $\begin{array}{l}\text { Indeks } \\
\text { Vegetasi }\end{array}$ & Tinggi & Sedang & Tinggi & Rendah \\
Lanjut & & & & \\
(AVI) & & & &
\end{tabular}

(AVI)

Indeks Rendah Rendah Rendah Tinggi

Tanah

Terbuka

(BI)

\begin{tabular}{lllll}
$\begin{array}{l}\text { Indeks } \\
\text { Bayan- } \\
\text { gan (SI) }\end{array}$ & Tinggi & Sedang & Rendah & Rendah \\
$\begin{array}{l}\text { Indeks } \\
\text { Suhu }\end{array}$ & Rendah & Sedang & Sedang & Tinggi \\
(TI) & & & & \\
\hline
\end{tabular}

Sumber : Rikimaru, 2002

Tabel 1. menerangkan karakteristik dari kombinasi antara empat indeks yang digunakan dalam pemodelan FCD. Berdasarkan tabel tersebut, dapat dijelaskan bahwa apabila nilai AVI tinggi maka kemungkinan besar nilai FCD pun tinggi dan nilai AVI yang rendah menunjukan nilai dari obyek berupa tanah terbuka. BI yang tinggi menunjukan obyek berupa tanah terbuka, dan nilai BI yang rendah kemungkinan besar menunjukan obyek vegetasi. Berbeda halnya dengan SI yang menunjukan penurunan nilai seiring dengan berkurangnya nilai FCD, dan SI memiliki nilai yang rendah untuk obyek berupa semak dan tanah terbuka. TI berbanding terbalik dengan SI. Nilai TI justru meningkat dengan semakin berkurangnya vegetasi. Nilai TI tinggi pada obyek berupa tanah terbuka dan rendah pada daerah dengan FCD yang tinggi.

Kerapatan vegetasi (VD) merupakan salah satu hasil sintesis AVI dan BI. Kerapatan vegetasi yang dimaksud adalah kelindungan atau proporsi permukaan tanah yang ditutupi oleh proyeksi tajuk tumbuhan. Pemrosesan metode ini menggunakan Principal Component Analysis (PCA) karena AVI dan BI memiliki korelasi yang negatif. (Rikimaru, 1996 dalam Rikimaru, 2002 ; Danoedoro, 2012).

Indeks berupa SSI adalah nilai histogram SI yang telah disesuaikan dengan TI untuk membedakan hutan dan vegetasi permukaan tanah dari segi bayangan dan suhu permukaan. Area yang memiliki nilai SSI nol menunjukan hutan yang memiliki nilai bayangan terendah sedangkan pada area yang memiliki nilai SSI 100 menunjukan hutan yang memiliki nilai bayangan tertinggi. Dengan pengembangan SSI maka akan dapat dibedakan antara vegetasi kanopi dan vegetasi yang berada di tanah. (Jamalabad, 2000 ; Rikimaru, 2002) Integrasi dari VD dan SSI menghasilkan nilai kerapatan kanopi hutan. Nilai indeks kerapatan kanopi hutan tersebut dihitung menggunakan persaman :

$\mathrm{FCD}=(\mathrm{VDxSSI}+1) 1 / 2-1$

Integrasi model tersebut kemudian akan menghasilkan data kerapatan kanopi per piksel. Presentase FCD bernilai 0\% sampai dengan 100\%. $0 \%$ menunjukan ketiadaan liputan tajuk dan daerah tersebut didominasi oleh lahan terbuka. Seiring dengan semakin besar nilai presentase FCD, semakin luas area piksel yang diliputi oleh tajuk. Selain itu terdapat perbedaan strata yang semakin jelas dan meningkatnya heterogenitas sehingga cahaya matahari tidak dapat menembus hingga ke lantai hutan.

Hasil pemodelan kerapatan kanopi hutan Gunung Kelud sebelum dan sesudah erupsi kemudian diuji akurasi menggunakan metode Standart Error of Estimation (SEE). SEE merupakan metode uji akurasi yang mempertimbangkan selisih antara kerapatan kanopi hasil pemodelan dengan kerapatan aktual hasil pengukuran lapangan. Pengukuran lapangan untuk mendapatkan kerapatan kanopi aktual dilaksanakan pada bulan Maret 2016 dengan jumlah titik sampel sebanyak 41 buah. Hasil pemodelan FCD yang telah diuji akurasi selanjutnya digunakan untuk menganalisi perubahan kerpatan kanopi setelah erupsi tahun 2014

Peta kerapatan kanopi hasil pemodelan FCD baik pada tahun 2013 (sebelum erupsi) dan 2015 (sesudah erupsi) digunakan untuk mendeteksi perubahan kerapatan kanopi dengan metode combine pada ArcGIS 10.2. Metode tersebut akan menghasilkan informasi perubahan kerapatan baik dalam bentuk tabel maupun peta. Combine merupakan salah satu metode overlay raster, dimana setiap piksel pada posisi geografis yang sama dengan dua waktu perkeman berbeda (atau dalam hal ini dapat pula disebut cell) dianalisis perubahannya dan kemudian diberi identitas baru sesuai perubahannya tersebut. Berdasarkan hasil pemodelan FCD tahun 2013 (sebelum erupsi) dan 2015 (sesudah erupsi), dilakukan proses tumpangsusun untuk mendapatkan data luasan wilayah yang mengalami perubahan serta analisis perubahan kerapatan kanopi. 


\section{HASIL DAN PEMBAHASAN}

Advanced Vegetation Index (AVI), Bare Soil Index (BI), Shadow Index atau Scaled Shadow Index (SSI) dan Thermal Index (TI) diolah menggunakan software FCD Mapper untuk kemudian menghasilkan kerapatan kanopi atau FCD dalam satuan persen (\%). Perhitungan AVI dan BI dengan citra Landsat terkoreksi topografi juga menghasilkan kerapatan vegetasi (VD) dalam satuan persen. Adapun hasil VD untuk citra Landsat 8 perekaman 26 Juni 2013 dan 4 september 2015 dapat dilihat pada Gambar 1.

Gambar 1. menunjukan rendahnya kerapatan vegetasi di bagian puncak gunung pada hasil VD tanggal 23 Juni 2013, sedangkan pada daerah di sekeliling puncak terdapat kerapatan vegetasi antara $60 \%$ hingga $100 \%$ dan terdapat sedikit kerapatan vegetasi $40-50 \%$. Berbeda halnya dengan kerapatan vegetasi pada saat setelah erupsi (Citra Landsat 8 perekaman 4 September 2015), pada daerah sekitar puncak gunung didominasi oleh kerapatan vegetasi $0-10 \%$. Hal ini mengindikasikan dampak dari erupsi tahun 2014 terhadap vegetasi di Gunung Kelud, dimana kerapatan vegetasi berkurang drastis. Kelas kerapatan vegetasi yang paling dominan pada citra Landsat 8 perekaman tanggal 4 September 2015 adalah kelas kerapatan vegetasi $0-10 \%$ sedangkan pada citra Landsat 8 perekaman 26 Juni 2013 adalah kerapatan vegetasi $60-70 \%$.

Hasil SSI untuk citra Landsat 8 perekaman 26 Juni
2013 dan 4 September 2015 ditampilkan pada Gambar 2.

Terlihat pada Gambar 2. bahwa nilai SSI pada citra Landsat 8 perekaman 26 Juni 2013 didominasi oleh rentang $70-100 \%$ sehingga kenampakannya didominasi oleh warna hijau. Kerapatan $>90 \%$ terlihat berada pada lereng-lereng gunung yang berarti menunjukkan temperatur rendah dan bayangan tinggi, kondisi tersebut identik dengan kondisi kerapatan vegetasi tinggi. Hal ini secara tidak langsung menunjukan bahwa daerah Gunung Kelud merupakan daerah bervegetasi rapat, dimana suhu relatif rendah dengan bayangan yang tinggi.

Citra Landsat 8 perekaman 4 September 2015 didominasi oleh nilai SSI dengan rentang 80-100\% dan terdapat perbedaan signifikan pada area puncak yaitu adanya nilai SSI dengan rentang 0-10\% yang lebih luas dibandingkan dengan di perekaman 26 Juni 2013. Nilai SSI yang rendah menunjukan nilai indeks temperatur yang tinggi dan nilai indeks bayangan yang rendah. Hal tersebut sesuai dengan kondisi area puncak Gunung Kelud yang terdampak erupsi, dimana vegetasi berkurang atau bahkan hilang dan menjadi tanah terbuka yang memiliki temperatur relatif tinggi dan minimnya bayangan. Berdasarkan hal tersebut maka dapat disimpulkan bahwa hasil SSI untuk citra Landsat 8 perekaman 4 September 2015 cukup akurat dengan kondisi setelah erupsi tahun 2014.

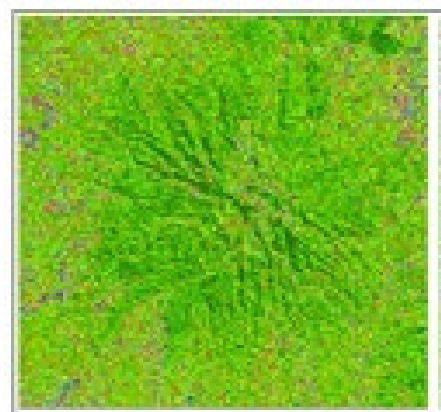

23 Juni 2013

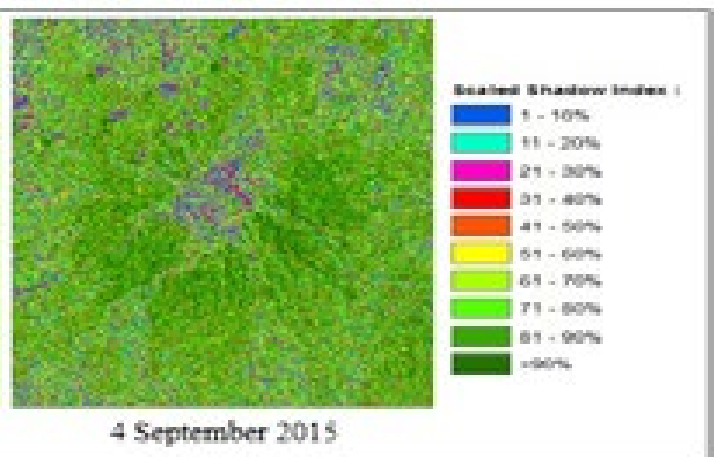

4 September 2015

Gambar 1. Kerapatan Vegetasi citra Landsat 8.

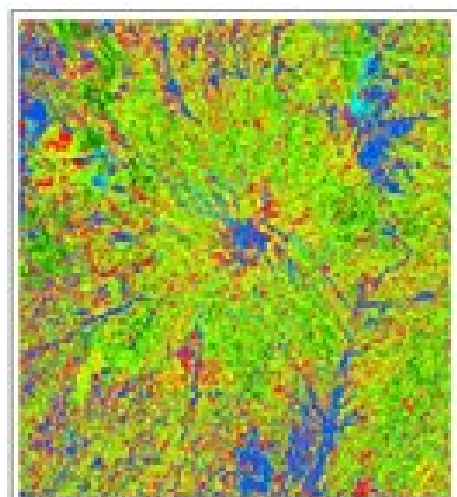

23 Jun 2013

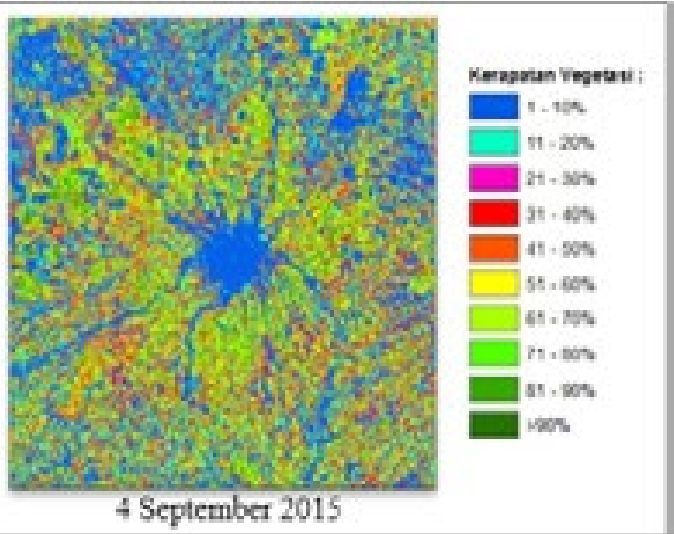

4 September 2015

Gambar 2 .Scaled shadow index citra Landsat 8. 
VD dan SSI kemudian diolah untuk menghasilkan estimasi FCD dalam rentang 0-100 yang diasumsikan sebagai persen per piksel. FCD tahun 2013 dan tahun 2015 kemudian di reklasifikasi menjadi 10 kelas agar mempermudah proses deteksi perubahan kerapatan kanopi. Hasil FCD baik untuk citra Landsat 8 perekaman 26 Juni 2013 dan perekaman 4 September 2015 dapat dilihat pada Gambar 3. dan Gambar 4.

Peta Kerapatan Kanopi Gunung menggunakan simbol warna yang menyesuaikan hasil pemodelan pada FCD Mapper yaitu biru, cyan, magenta, merah, oranye, kuning, dan gradasi dari hijau muda ke hijau tua. Kenampakan kerapatan kanopi pada Gambar 3. terutama didominasi oleh kerapatan $72-80 \%$

Tabel 2.Jumlah Piksel dan Luas per Kelas Kerapatan Kanopi sebelum erupsi

\begin{tabular}{lll}
\hline Kerapatan & Jumlah Piksel & Luas (Ha) \\
\hline $1-10 \%$ & 4249 & 382,41 \\
$11-20 \%$ & 990 & 89,10 \\
$21-30 \%$ & 4941 & 444,69 \\
$31-40 \%$ & 7555 & 679,95 \\
$41-50 \%$ & 9608 & 864,72 \\
$51-60 \%$ & 18045 & 1624,05 \\
$61-70 \%$ & 38818 & 3493,62 \\
$71-80 \%$ & 52210 & 4698,90 \\
$81-90 \%$ & 11437 & 1029,33 \\
$>90 \%$ & 72 & 6,48 \\
\hline
\end{tabular}

dengan luas 4698,90 Ha. Kelas kerapatan tersebut merepresentasikan kondisi hutan dengan tajuk meliputi $71-80 \%$ areal piksel dengan perbedan strata tegakan jelas terlihat serta heterogenitas jenis semakin meningkat. Berdasarkan tabel 3.1 dapat terlihat bahwa kelas kerapatan yang paling sedikit jumlah pikselnya adalah kerapatan $>90 \%$ dengan luas $6,48 \mathrm{Ha}$. Luas dan jumlah piksel untuk setiap kelas kerapatan kanopi hutan Gunung Kelud sebelum erupsi ditampilkan pada tabel Tabel 2.

Apabila diamati secara visual melalui peta, dapat terlihat bahwa warna yang mendominasi adalah gradasi hijau, atau kerapatan 51-90\%, dan kenampakan yang paling kontras terlihat adalah adanya kerapatan

Tabel 3. Jumlah Piksel dan Luas per Kelas Kerapatan Kanopi sesudah erupsi

\begin{tabular}{lll}
\hline Kerapatan & Jumlah Piksel & Luas (Ha) \\
\hline $1-10 \%$ & 30411 & 2878,80 \\
$11-20 \%$ & 5839 & 552,74 \\
$21-30 \%$ & 11283 & 1068,07 \\
$31-40 \%$ & 14918 & 1412,17 \\
$41-50 \%$ & 10570 & 1000,58 \\
$51-60 \%$ & 19159 & 1813,63 \\
$61-70 \%$ & 24408 & 2310,51 \\
$71-80 \%$ & 17249 & 1632,82 \\
$81-90 \%$ & 6792 & 642,94 \\
$>90 \%$ & 9 & 0,85 \\
\hline
\end{tabular}

Sumber : Hasil pengolahan data (2016)

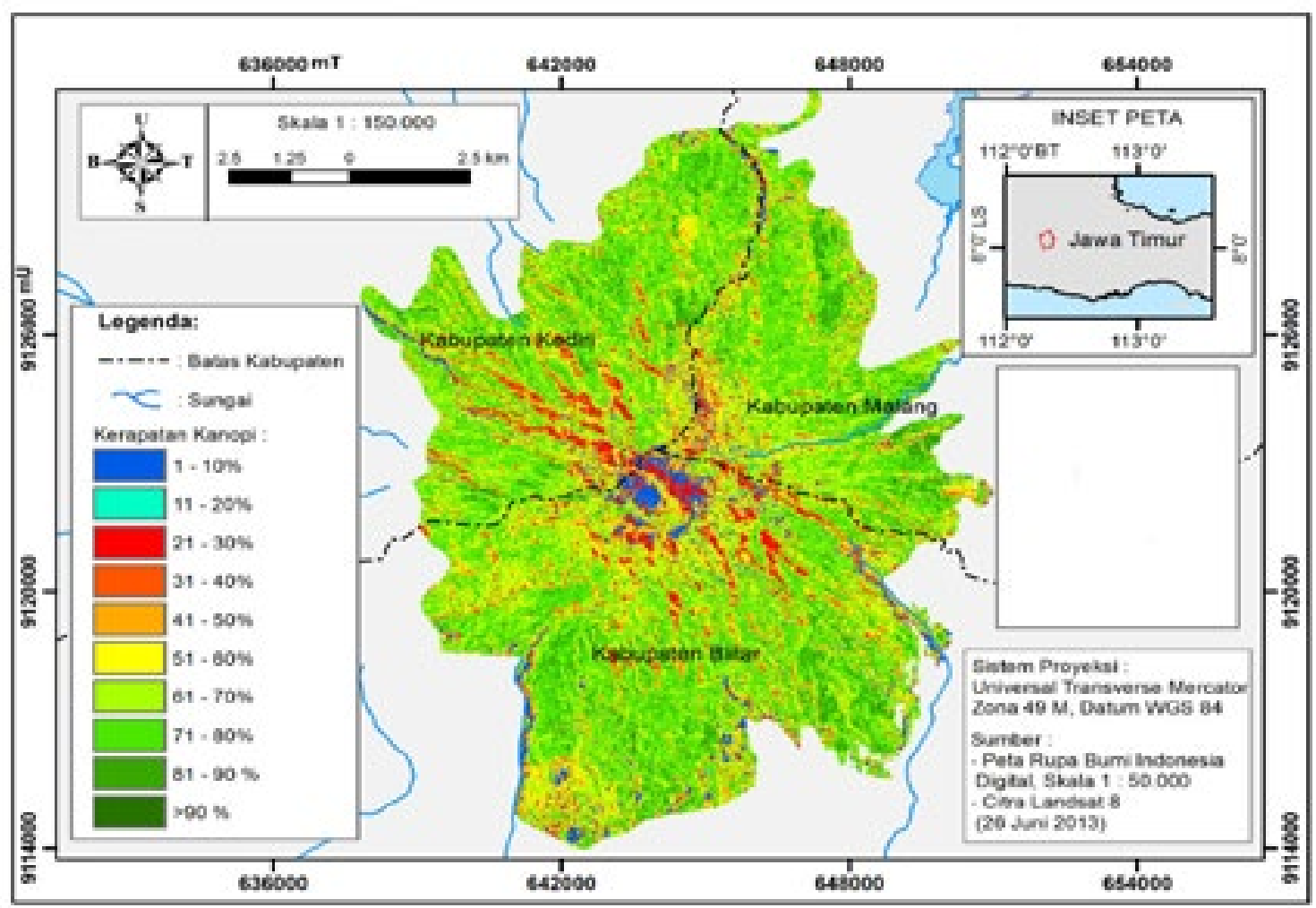

Gambar 3. Peta Kerapatan Kanopi Hutan Gunung Kelud Sebelum Erupsi Tahun 2014 


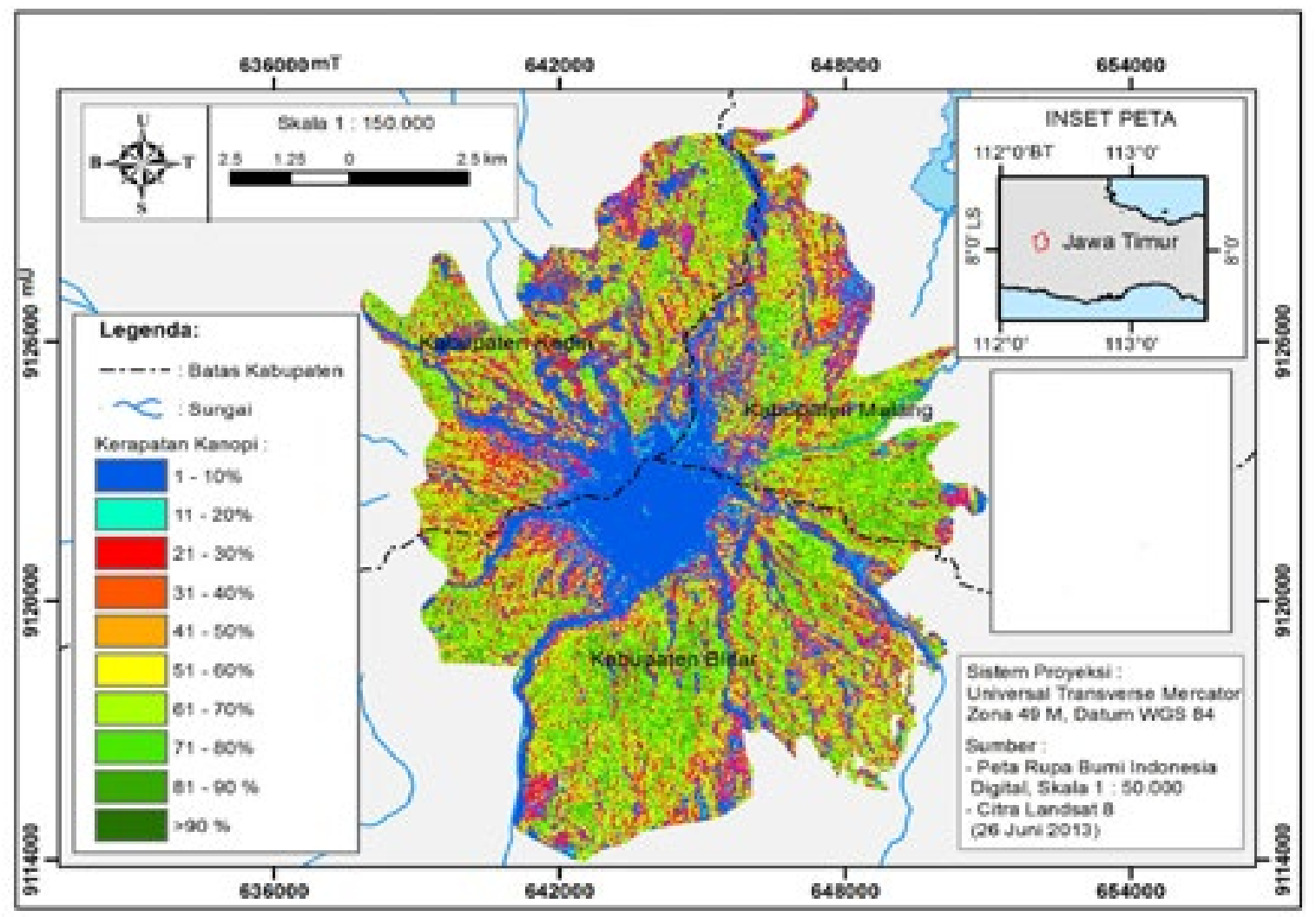

Gambar 4. Peta Kerapatan Kanopi Hutan Gunung Kelud Setelah Erupsi Tahun 2014

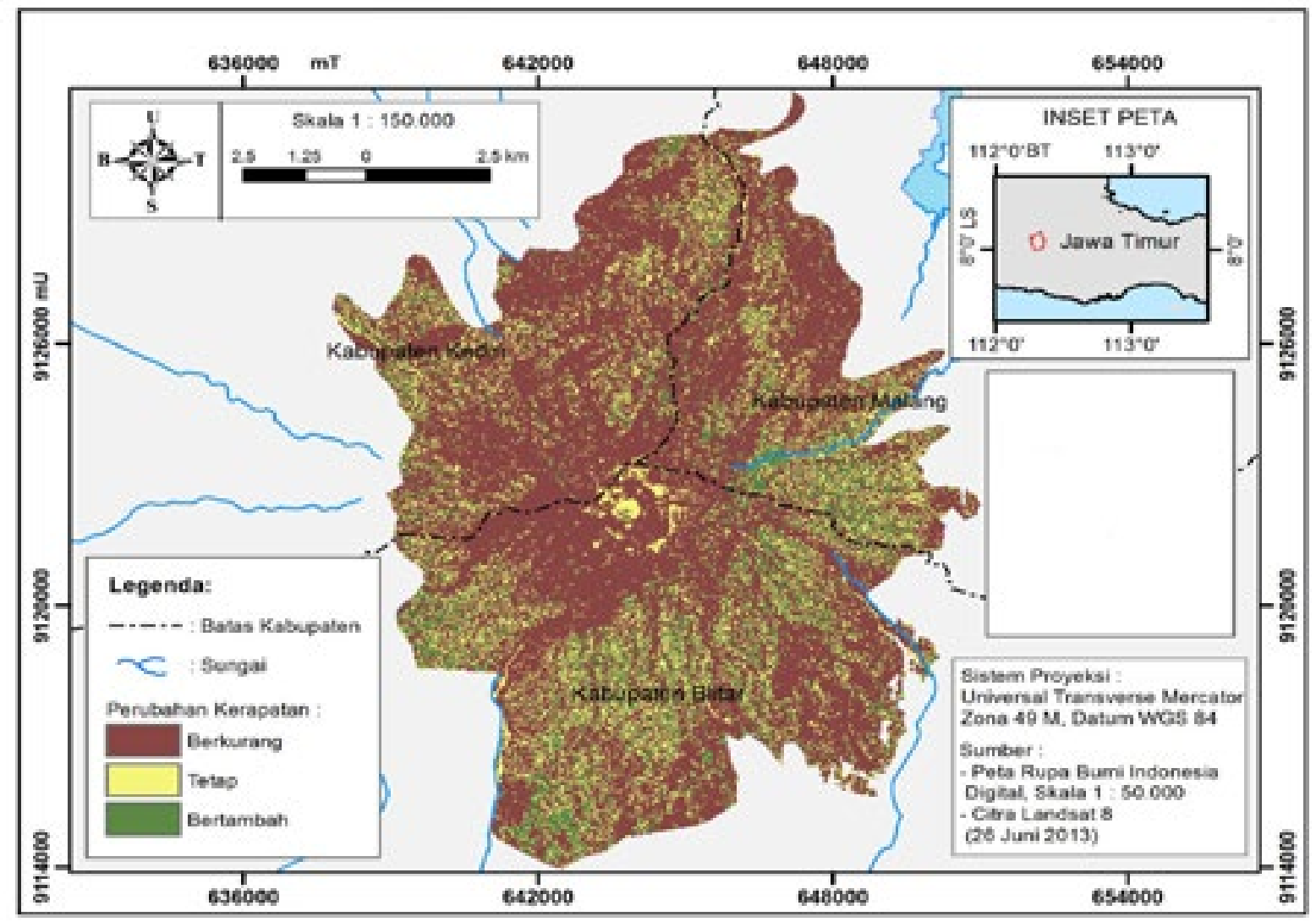

Gambar 5. Peta Kerapatan Kanopi Hutan Gunung Kelud Sebelum Erupsi Tahun 2014 
berwarna merah (21-30\%) yang berbentuk memanjang seperti menyerupai lereng-lereng gunung.

Peta Kerapatan Kanopi Gunung Kelud Setelah Erupsi Tahun 2014 memiliki kerapatan kanopi $1-10 \%$ yang terlihat jauh lebih luas. Kerapatan Kanopi $1-10 \%$ terletak di tengah atau puncak gunung dan di sekitar alur-alur sungai ke berbagai arah. Adapun luas kerapatan 1-10\% adalah seluas 2878,8 Ha. Kelas kerapatan kanopi Setelah Erupsi berdasarkan luas dan jumlah piksel disajikan pada Tabel 3.

Kelas kerapatan kanopi yang juga cukup mendominasi adalah kelas 61-70\% dengan luas 2310,51 Ha. Apabila diamati pada gambar 3.6 dapat terlihat kelas kerapatan 21-30\% yang menyebar dari puncak gunung Kelud ke berbagai arah. Kelas kerapatan 21$30 \%$ memiliki luas 1068,07 Ha dan berwarna magenta. Uji akurasi yang dilakukan pada FCD tahun 2013 dan FCD tahun 2015 menghasilkan nilai akurasi masingmasing sebesar $83,73 \%$ dan $81,14 \%$. Hal ini menunjukan tingkat akurasi yang baik, sehingga memungkinkan untuk melanjutkan ke analisis perubahan kerapatan kanopi.

Peta Perubahan Kerapatan Kanopi Gunung Kelud Setelah Erupsi tahun 2014 berisikan informasi mengenai perubahan kerapatan kanopi Hutan Gunung Kelud per piksel. Adapun luas hutan yang mengalami penurunan kerapatan kanopi adalah seluas 8833,95 Ha, sedangkan kerapatan kanopi tetap adalah seluas $2481,84 \mathrm{Ha} \mathrm{Ha}$, dan hutan yang mengalami peningkatan kerapatan kanopi adalah seluas 1975,77Ha.

Perubahan kerapatan kanopi pada peta ditampilkan dengan simbol berupa warna yang kontras untuk mempermudah penyampaian informasi. Kerapatan kanopi yang mengalami penurunan (berkurang) diberi warna merah, kerapatan kanopi tetap ditampilkan dengan warna kuning, dan kerapatan kanopi yang bertambah diberi warna hijau. Berdasarkan Peta Perubahan Kerapatan Kanopi Hutan Gunung Kelud Setelah Erupsi Tahun 2014, kelas perubahan kerapatan yang paling mendominasi adalah kerapatan kanopi yang berkurang (merah). Erupsi menyebabkan sebagian besar hutan Gunung Kelud mengalami penurunan kerapatan kanopi, penurunan tersebut tersebar baik di Kabupaten Kediri, Kabupaten Malang, Maupun Kabupaten Blitar. Kerapatan kanopi yang tetap maupun bertambah juga terlihat menyebar, namun dengan luas yang jauh lebih sedikit dibandingkan dengan kerapatan kanopi yang berkurang.

\section{KESIMPULAN}

Uji akurasi yang dilakukan pada hasil pemodelan Forest Canopy Density (FCD) tahun 2013 dan Tahun 2015 dengan hasil uji akurasi sebesar 83,73\% untuk FCD tahun 2013 dan 81,14\% untuk FCD tahun 2015. Terjadi perubahan luas kerapatan kanopi setelah erupsi, dimana terdapat $8833,95 \mathrm{Ha}$ hutan yang mengalami penurunan kerapatan kanopi yang mendominasi dan tersebar baik di Kabupaten Kediri, Kabupaten Malang,
Maupun Kabupaten Blitar, sedangkan hutan dengan kerapatan kanopi yang tetap adalah seluas 2481,84 Ha, dan hutan yang mengalami peningkatan kerapatan kanopi adalah seluas 1975,77 Ha.

\section{DAFTAR PUSTAKA}

Azizi, Z., Najafi, A., \& Sohrabi, H., (2008), Forest Canopy Density Estimating, Using Satellite Image. The International Archive of the Photogrammetry, Remote Sensing and Spatial Information Science. XXXVII. B8. Beijing 2008.

Chuvieco, E., \& Huete, A. (2010), Fundamentals of Satellite Remote Sensing. CRC Press. United States of America.

Danoedoro, P. (2012), Pengantar Penginderaan Jauh Digital. Penerbit ANDI. Yogyakarta.

Indriyanto. 2012, Ekologi hutan. Bumi Aksara. Jakarta ITTO/JOFCA. (2003), FCD-Mapper Ver.2 User Guide, Semi-Expert Remote Sensing System for Canopy Density Mapping.

Jamalabad, M. S., Akbar, A. A. (2000), Forest Canopy Density Monitoring, Using Satellite Images. ISPRS Commission VII (17). Holland.

Janssen, L. L. F., Bakker, W. H., Weir, M. J. C., et al. (2000), Principle of Remote Sensing. ITC, Endschede. Netherlands.

Loyd, C. (2013), Landsat Science : Landsat 8 Bands, (melalui http:/www. landsat.gsfc.nasa.gov/?page_ $\mathrm{id}=5377$, diakses pada tanggal 21 Desember 2014)

Panta, M. (2003), Analysis of Forest Cover Density and Factors Affecting It Using RS and GIS Technique (A Case Study from Chitwan District of Nepal). International Institute For Geo-Information Science and Earth Observation, Enschede. The Netherlands.

Pemerintah Republik Indonesia. (2008), Peraturan Pemerintah Republik Indonesia nomor 76 tahun 2008 tentang Rehabilitasi dan Reklamasi Hutan. Jakarta.

Riano, D., Chuvieco, E., Salas, J., et al. (2003), Assessment of Different Topographic Corrections in LandsatTM Data for Mapping Vegetation Types. IEEE Transactions on Geoscience And Remote Sensing, Vol. 41, No. 5, May 2003 : 1056-1061

Rikimaru, A., Roy, P. S., \& Miyatake, S. (2002), Tropical Forest Density Mapping. Tropical Ecology 43(1) : 39-47.

Yulianto, S. (2010), Kajian Kemampuan Model Forect Cover Density (FCD) Berbasis Citra Landsat ETM+ Multitemporal untuk Memantau Suksesi Hutan Rawa Gambut di Kalimantan Tengah. Fakultas Geografi, Universitas Gadjah Mada. Yogyakarta. 